\title{
House Dust Mite Allergen Inhibits Constitutive Neutrophil Apoptosis by Cytokine Secretion via PAR2/PKC /p38 MAPK Pathway in Allergic Lymphocytes
}

\author{
Na Rae Lee ${ }^{1}$, Ji-Sook Lee ${ }^{2}$, In Sik Kim ${ }^{1,3}$ \\ ${ }^{1}$ Department of Biomedical Laboratory Science, School of Medicine, Eulji University, Daejeon 34824, Korea \\ ${ }^{2}$ Department of Clinical Laboratory Science, Wonkwang Health Science University, Iksan 54538, Korea \\ ${ }^{3}$ Department of Senior Healthcare, BK21 Plus Program, Graduate School, Eulji University, Daejeon 34824, Korea
}

\section{알레르기 림프구에서 집먼지진드기 알러젠의 PAR2/PKC $/ \mathrm{p} 38$ MAPK 경로를 통한 사이토카인 증가는 호중구의 세포고사를 억제시킨다}

\author{
이나래 ${ }^{1}$, 이지숙 ${ }^{2}$, 김인식 ${ }^{1,3}$ \\ ${ }^{1}$ 을지대학교 대전캠퍼스 임상병리학과, ${ }^{2}$ 원광보건대학교 임상병리과, ${ }^{3}$ 을지대학교 대전캠퍼스 BK21 플러스 프로그램 시니어 헬스케어학과
}

\begin{abstract}
Neutrophils and lymphocytes are essential inflammatory cells in the pathogenesis of allergy. In this study, we evaluated the role of house dust mite (HDM) in the interaction between allergic lymphocytes and neutrophils. The extract of Dermatophagoides pteronissinus (DP) showed a stronger anti-apoptotic impact on neutrophil apoptosis in the coculture of allergic neutrophils with allergic lymphocytes when compared with that in allergic neutrophils alone. DP increased IL-6, IL-8, MCP-1, and GM-CSF in allergic lymphocytes, and the increased cytokines were inhibited by rottlerin-an inhibitor of the protein kinase C (PKC) $\delta$, as well as by SB202190-a p38 MAPK inhibitor. DP activated p38 MAPK in a time-dependent manner. The activation of p38 MAPK was suppressed by PAR2i, which is a protease-activated receptor (PAR) 2 inhibitor, and rottlerin. Both aprotinin - a serine protease inhibitor-and E64-a cysteine protease inhibitor-were not effective on cytokine secretion of lymphocytes. These results, despite increased cytokines in allergic lymphocytes via DP, did not show any differences between asthma and allergic rhinitis. Molecules, including cytokines, released by DP in lymphocytes inhibited the migration of neutrophils. This finding may further elucidate the pathogenic mechanism of allergic diseases due to HDM.
\end{abstract}

Key words: House dust mite, Cytokine, Neutrophils apoptosis, Allergy

This is an Open Access article distributed under the terms of the Creative Commons Attribution Non-Commercial License (http://creativecommons.org/licenses/by-nc/4.0) which permits unrestricted non-commercial use, distribution, and reproduction in any medium, provided the original work is properly cited.

Copyright (ㅇ 2016 The Korean Society for Clinical Laboratory Science. All rights reserved.
Corresponding author: In Sik Kim Department of Biomedical Laboratory Science School of Medicine, Eulji University, 77 Gyeryoung-ro 771 beon-gil, Jung-gu, Daejeon 34824, Korea

Tel: 82-42-259-1753

Fax: 82-42-259-1759

E-mail: orientree@eulji.ac.kr

Received: May 31, 2016

Revised: June 23, 2016

Accepted: June 28, 2016
Introduction

Allergic diseases are characterized by elevated IgE in response to house dust mite (HDM) and inflammatory responses, depending on survival and migration of leucocytes [1-3]. HDMs are mainly composed of Dermatophagoides pteronissinus (DP) and Dermatophagoides farinae. HDM exposure initiates allergic diseases, such as asthma, allergic 
rhinitis, and atopic dermatitis, as well as aggravating symptoms of the diseases by increased inflammation [4,5]. The pathogenic mechanism is caused by allergen proteins contained in HDM, such as serine and cysteine proteases, lipid-binding protein, and chitinase [6,7]. It has been recently reported that regulation of neutrophil apoptosis due to HDM is important in the pathogenesis of asthma and allergic rhinitis [8-10].

Regulation of cytokine secretion in lymphocytes is an essential process of the pathogenesis of allergic diseases. Regarding allergic inflammation, IL-6 induces the transition from acute to chronic stage [11]. MCP-1/CCL2 and IL-8/CXCL8 play roles as chemoattractants, inducing monocytes and neutrophils, respectively [12,13]. Moreover, GM-CSF induces the differentiation of granulocyte precursors [9]. These cytokines are involved in the proliferation and anti-apoptotic action of neutrophils [9,10].

We have reported that HDM induces the cytokines associated with neutrophil survival in lymphocytes, which regulate neutrophil apoptosis via the PAR2/PI3K/Akt/ERK/NF-кB pathway [14]. In this study, we examined another PAR2-mediated signal mechanism due to HDM in allergic lymphocytes. We also investigated the difference of cytokine secretion due to HDM between asthma and rhinitis, as well as the effects of secreted molecules induced by HDM on neutrophil chemotaxis.

\section{Materials and Methods}

\section{Reagents}

RPMI 1640 and fetal bovine serum (FBS) were purchased from Life Technologies Inc. (Gaithersburg, MD, USA). DP was obtained from Cosmo Bio (Tokyo, Japan). Rottlerin and SB202190 were purchased from Calbiochem (San Diego, CA, USA). ENMD-1068, a PAR2 antagonist (PAR2i), was purchased from Enzo Life Sciences (Farmingdale, NY, USA). The protease inhibitors, aprotinin and E64 were purchased from Sigma-Aldrich (St. Louis, MO, USA). Antibodies against phospho-p38 MAPK and p38 MAPK were obtained from Santa Cruz Biotechnology (Santa Cruz, CA, USA).

\section{Normal and allergic subjects}

A total of 27 allergy patients were recruited from Eulji University Hospital. Allergic status was based on the presence of positive results of a skin prick test $(\geq 2+)$, multiple allergen simultaneous test (MAST) ( $\geq$ class 2 ), or evaluation of specific HDM IgE using the Pharmacia Unicap 100 system (Pharmacia, Uppsala, Sweden) for common allergens ( $\geq 100 \mathrm{IU} / \mathrm{ml}$ ). The normal subjects $(n=3)$ had no history of asthma or allergic rhinitis. This study was approved by the Institutional Review Board of Eulji University for normal volunteers and the Institutional Review Board of Eulji University Hospital for allergic patients [2015-07-022]. All participants in this study gave their written informed consent.

\section{Isolation of lymphocytes and neutrophils and cell culture}

Human lymphocytes and neutrophils were separated from the heparinized peripheral blood $(10 \mathrm{~mL})$ of healthy persons and allergic subjects using Ficoll-Hypaque gradient centrifugation. A CD16 microbeads magnetic cell sorting kit and a monocyte isolation kit II (Miltenyi Biotec, Bergisch Gladbach, Germany) were used for neutrophil and lymphocyte separation, respectively. The cells were washed after hypotonic lysis to remove erythrocytes. Neutrophils and lymphocytes were resuspended at $3 \times 10^{6} / \mathrm{ml}$ and $2 \times 10^{6} / \mathrm{ml}$ in RPMI 1640 medium with $1 \%$ penicillin-streptomycin and $10 \%$ FBS.

\section{Enzyme-linked immunosorbent assay (ELISA)}

The concentrations of IL-6, IL-8, GM-CSF, and MCP-1 in a cell supernatant were measured with a sandwich enzyme-linked immunosorbent assay (ELISA) using OptEIA ${ }^{\mathrm{TM}}$ Set human IL-6, IL-8, GM-CSF, and MCP-1 (BD Biosciences, San Diego, CA, USA) according to the manufacturer's instructions.

\section{Detection of apoptosis}

An annexin V-fluorescein isothiocyanate (FITC) apoptosis detection kit (BD Biosciences, San Diego, CA, USA) was used for detection of neutrophil apoptosis. Isolated neutrophils were treated with DP, then incubated with FITC-labeled annexin $\mathrm{V}$ and propidium iodide (PI) for $15 \mathrm{~min}$ at room 
temperature. Apoptotic neutrophils showing annexin V+/PIand annexin V+/PI+ were analyzed using a FACSCalibur flow cytometer with the CellQuest software (BD bioscience) and were reported as the percentage.

\section{Western blotting}

After being treated with DP, cells were harvested and lysed in Ceti lysis buffer (TransLab, Daejeon, Korea). The lysate was centrifuged at $12,000 \times \mathrm{g}$ for $15 \mathrm{~min}$ at $4^{\circ} \mathrm{C}$, after which the supernatant was collected. The protein samples (50 $\mu \mathrm{g} /$ lane) were separated by SDS-polyacrylamide gel electrophoresis, after which they were transferred to membranes and incubated with anti-phospho p38 MAPK antibodies and developed using the enhanced chemiluminescence detection system (Amersham Pharmacia Biotech, Piscataway, NJ, USA). The same blot was stripped and reprobed with anti-p38 MAPK antibodies for use as an internal control.

\section{Chemotaxis assay}

The activity of cell migration was estimated using a 48-well microchamber (Neuroprobe, Gaithersburg, MD, USA). The lower wells were filled with $28 \mu \mathrm{L}$ buffer alone or with buffer containing IL-8. A polyvinylpyrrolidone (PVP)-free filter with $5 \mu \mathrm{m}$ pore size was placed over each lower well. Cell

A

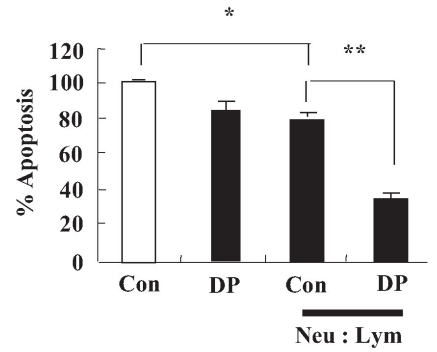

B

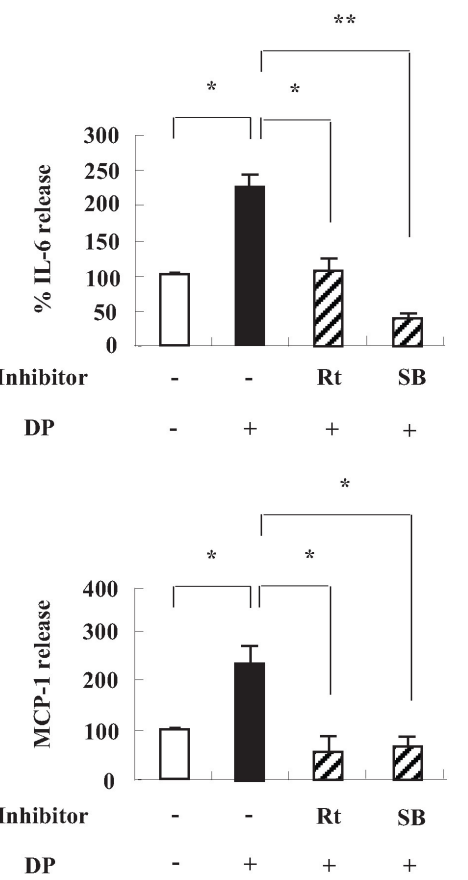

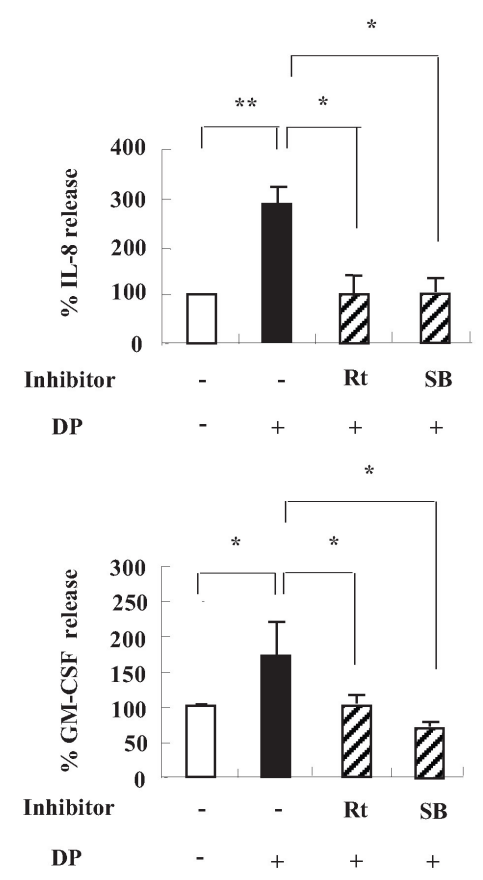

Fig. 1. The secretion of $\| \mathrm{L}-6, \mathrm{~L}-8$, MCP-1, and GM-CSF is inhibited by rottlerin and SB202190 in allergic lymphocytes. (A) Allergic neutrophils or neutrophils and lymphocytes (1:1 ratio) ( $\mathrm{n}=4)$ were incubated for $24 \mathrm{hr}$ in the absence and presence of DP $(10 \mu \mathrm{g} / \mathrm{mL})$. Apoptosis was analyzed by measuring the binding of annexin $\mathrm{V}$-FITC and PI. (B) Allergic lymphocytes $(3<n<5)$ were pre-treated for $1 \mathrm{hr}$ with and without PAR2i, $5 \mu \mathrm{M}$ rottlerin (Rt), and $20 \mu \mathrm{M}$ SB202190, after which the cells were incubated for 24 $\mathrm{hr}$ in the absence and presence of DP $(10 \mu \mathrm{g} / \mathrm{mL})$. The supernatant was collected and analyzed by ELISA. Data are expressed as the means \pm S.E.M. ${ }^{*} p<0.05$ and ${ }^{* *} p<0.01$ indicate a significant difference. 
suspension was added with $50 \mu \mathrm{L}$ of neutrophils at $2 \times 10^{6}$ cells $/ \mathrm{mL}$ to the upper wells. The assembled chamber was incubated for $90 \mathrm{~min}$ at $37^{\circ} \mathrm{C}$ in a humidified incubator. Non-migrated cells adhering to the upper surface of polycarbonate filter were removed with a filter wiper. The fi lter was dried, fixed, and stained with Diff-Quick (Baxter, McGaw Park, IL, USA). The cells from four randomly selected fields per well were counted, and a single experiment includes six replicate measurements.

\section{Statistical analysis}

Data were expressed as the means \pm S.E.M. Statistical differences were analyzed using a paired t-test for two-group comparisons and one-way ANOVA for comparison of more than two groups. All analyses were conducted using the SPSS statistical software package (Version 10.0, Chicago, IL, USA), and a $p$ value $<0.05$ was considered to indicate statistical significance.

\section{Results}

\section{The secretion of IL-6, IL-8, MCP-1, and GM-CSF} induced by DP was involved in PKC $\delta$ and p38 MAPK in allergic lymphocytes

To the best of our knowledge, this study is the first to confirm that secretory cytokines of DP treated-lymphocytes are related to neutrophil survival before investigating a PAR2-mediated signal mechanism induced by DP on cytokine secretion of allergic lymphocytes. Allergic neutrophils were cocultured with allergic lymphocytes, and the cells were treated with DP. Spontaneous neutrophil apoptosis was strongly suppressed by the coculture of neutrophils with lymphocytes after DP treatment, as compared with neutrophils alone (Fig. 1A). We then examined the alteration of cytokine after treatment with signal inhibitors. Both rottlerin and SB202190 significantly inhibited the production of IL-6, IL-8, $\mathrm{MCP}-1$, and GM-CSF increased by DP $(p<0.05)$ (Fig. 1B). Given these results, we examined the association of PKC $\delta$ and p38 MAPK with the effect of DP. p38 MAPK was phosphorylated by DP in a time-dependent manner, and the activation was inhibited by PAR2i and rottlerin (Fig. 2). In addition, both aprotinin - a serine protease inhibitor - and E64-a cysteine protease inhibitor had no effect on the alteration of cytokines induced by DP in normal and allergic lymphocytes; however, DP was closely associated with protease activity (Fig. 3).

\section{The effect of DP on cytokine release in allergic lymphocytes was not different between asthma and allergic rhinitis}

Since the pathogenic mechanisms of allergic diseases are different depending on the individual allergy, we examined the difference of increased cytokines in the lymphocytes of asthma and allergic rhinitis. As shown in Fig. 4, there was a lack of difference between asthma and allergic rhinitis in the cytokine production of lymphocytes by DP.

\section{The secretory molecules produced by allergic lymphocytes inhibited the neutrophil chemotaxis in response to IL-8}

Since the released cytokines due to DP alter neutrophil apoptosis and cell migration plays an important role in allergic inflammation, we examined whether the released molecules due to DP affect neutrophil migration. Supernatant
A

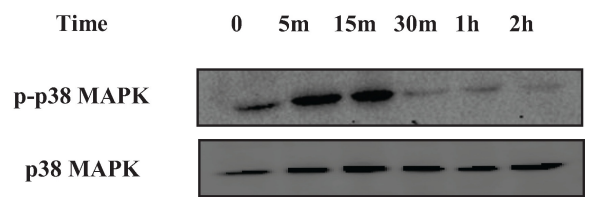

B

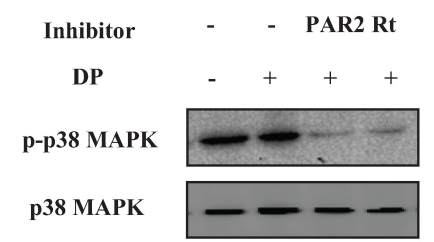

Fig. 2. DP activates $\mathrm{p} 38$ MAPK via PAR2 and PKC $\delta$ in allergic lymphocytes. (A) Normal lymphocytes were incubated with $\mathrm{DP}(10 \mu \mathrm{g} / \mathrm{mL})$ for the indicated time. (B) Normal lymphocytes were pre-treated for $1 \mathrm{hr}$ with and without PAR2i (B) and $5 \mu \mathrm{M}$ rottlerin (Rt), after which harvested cells were lysed and phosphorylation of p38 MAPK in the lysates was detected by Western blotting. 
A
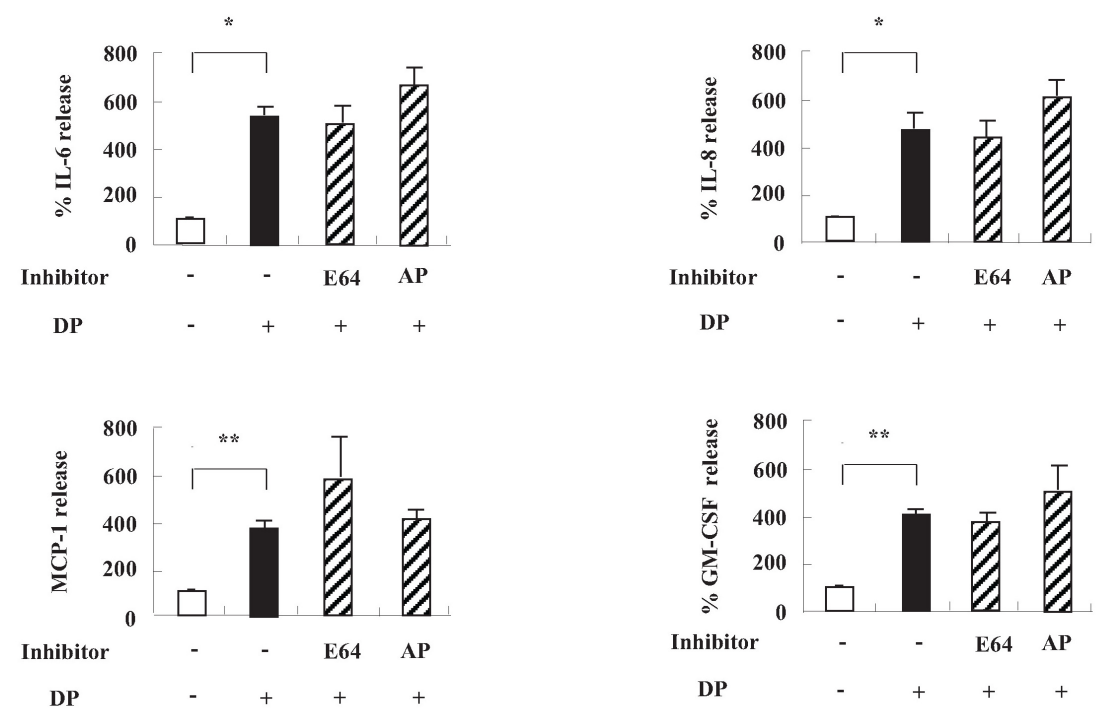

B
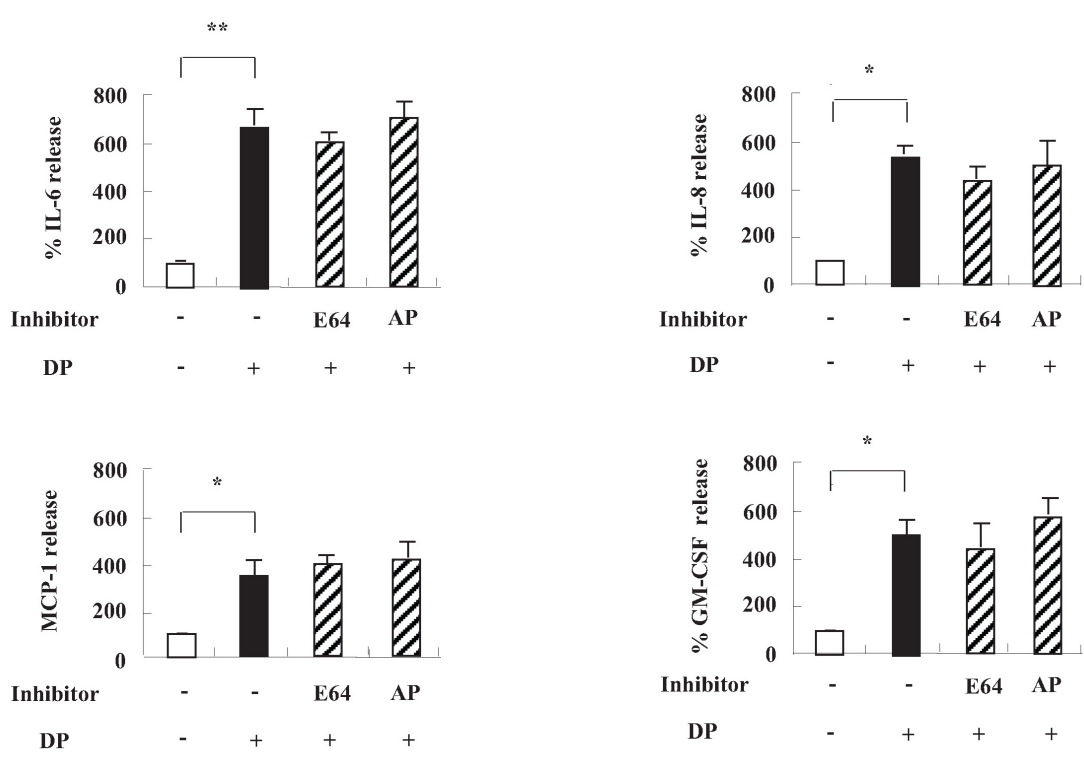

Fig. 3. The secretion of $I L-6, I L-8$, MCP-1, and GM-CSF due to DP is not associated with protease activity. Allergic (A) and normal (B) lymphocytes $(\mathrm{n}=3)$ were pre-treated for $1 \mathrm{hr}$ with and without $50 \mu \mathrm{g} / \mathrm{mL}$ E64 and aprotinin (AP), after which the cells were incubated for $24 \mathrm{hr}$ in the absence and presence of DP (10 $\mu \mathrm{g} / \mathrm{mL}$ ). The supernatant was collected and analyzed by ELISA. Data are expressed as the means \pm S.E.M. ${ }^{*} p<0.05$ and ${ }^{* *} p<0.01$ indicate a significant difference.

from allergic lymphocytes inhibited the neutrophil migration and DP-treated supernatant inhibited the movement more strongly (Fig. 5).

\section{Discussion}

House dust mite (HDM) is an important allergen that evokes and aggravates allergic diseases, including asthma and allergic rhinitis. The pathogenic mechanisms of these diseases are related to the dysregulation of various cytokines released from lymphocytes and survival of inflammatory leucocytes, specifically neutrophils [3-5]. As shown in Figs. 1 and 2, DP increased the cytokines released, which were involved in neutrophil survival. This mechanism was accomplished by the PAR2/PKC8/p38 MAPK pathway. PAR2 is closely involved in allergic disease. Thymic Stromal Lymphopoietin (TSLP), increased by PAR2 activation, induces or aggravates atopic dermatitis [15]. Transient PAR2 lowers 

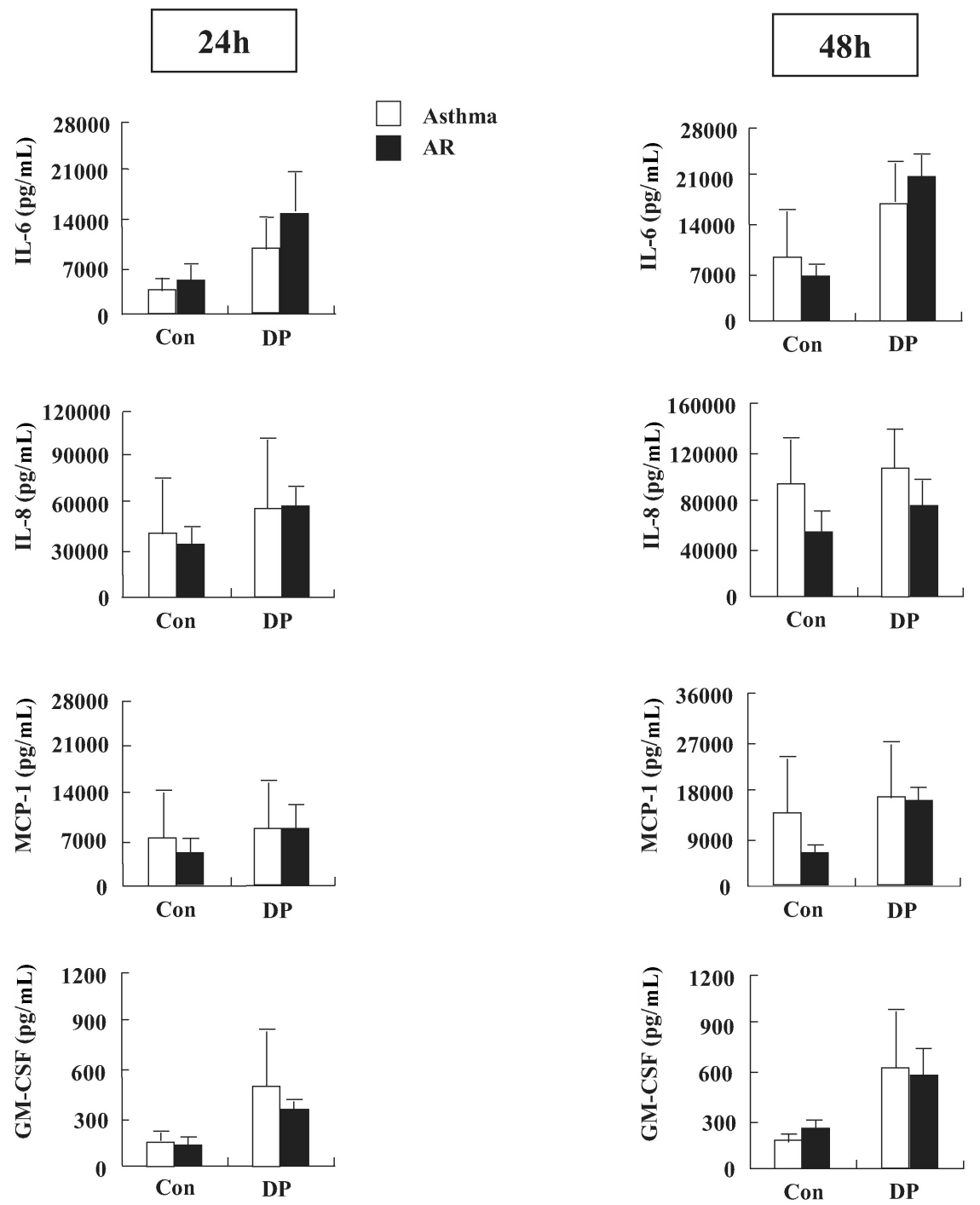

Fig. 4. The secretion of $I L-6, I L-8$, MCP-1, and GM-CSF due to DP is not different between asthma and allergic rhinitis. Asthma and allergic rhinitis lymphocytes $(n=10)$ were pre-treated for $1 \mathrm{hr}$ with and without DP (10 $\mu \mathrm{g} / \mathrm{mL}$ ), after which the cells were incubated for $24 \mathrm{hr}$ and $48 \mathrm{hr}$ in the absence and presence of DP (10 $\mu \mathrm{g} / \mathrm{mL}$ ). The supernatant was collected and analyzed by ELISA. Data are expressed as the means \pm S.E.M.

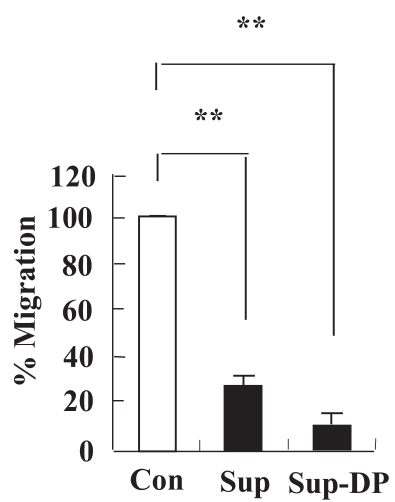

Fig. 5. The secretory molecules produced by allergic lymphocytes inhibit neutrophil chemotaxis in response to IL-8. Allergic lymphocytes $(4<n<6)$ were incubated in the absence or presence of $10 \mu \mathrm{g} / \mathrm{mL}$ of DP for $24 \mathrm{hr}$ and supernatant was collected. Neutrophils were treated with the supernatant, and a chemotaxis assay was performed. Data are presented relative to the control, which was set at $100 \%$ of the means \pm S.E.M. ${ }^{\star \star} p<0.01$ indicates a significant difference.

the bronchospasm by relaxing the airway smooth muscle. However, chronic PAR2 activation induces pro-inflammatory responses [16]. Studies on the association between PAR2 with PKC $\delta$ is lacking in the literature. PKC $\delta$ is involved in PAR2-mediated signal mechanism for the production of thromboxane in platelets [17]. The activation of PKC $\beta$ and PKC triggers basolateral PAR2-induced chloride secretion [18]. Our results show that ERK1/2 is not a downstream molecule of PKC 8 , but p38 MAPK, which is activated by DP in a time-dependent course (Fig. 2). These results indicate that the novel PAR2/PKC8/p38 MAPK pathway is an important signal mechanism in allergic diseases.

Apoptosis and movement of leucocytes are essential steps in the pathogenic mechanism of allergic diseases. HDM induces allergic diseases and aggravates the clinical features 
and symptoms of the diseases by altering the mechanisms of apoptosis and chemotaxis [19,20]. DP suppressed neutrophil apoptosis in the coculture of allergic neutrophils and lymphocytes. Moreover, it also inhibited the migration of neutrophils (Fig. 1A and Fig. 5). The molecules secreted by lymphocyte with no treatment also suppressed the chemotaxis of neutrophils, and the inhibitory effect was weaker than that of DP-treated supernatant. We believe that DP stops the movement of neutrophils and delays neutrophil apoptosis in inflammatory sites by activating lymphocytes. In summary, DP increases IL-6, IL-8, MCP-1, and GM-CSF via the PAR2/PKC /p38 MAPK pathway in allergic lymphocytes, and the secreted cytokines delay constitutive neutrophil apoptosis. These findings may shed light on the complex pathogenic mechanism of allergic diseases by understanding the interaction between lymphocytes and neutrophils.

\section{요 약}

본 연구에서는 집먼지 진드기 추출물은 호중구에 단독으로 작용 하는 것보다, 림프구와 호중구의 공동배양에서 호중구의 세포고사 를 더 억제시켰다. 집먼지 진드기는 알레르기 질환의 림프구에서 $\mathrm{IL}-6, \mathrm{IL}-8, \mathrm{MCP}-1, \mathrm{GM}-\mathrm{CSF}$ 의 분비를 증가시켰다. 집먼지 진드 기에 의해 증가된 사이토카인은 protein kinase $\mathrm{C} \delta$ 의 억제제인 rottlerin과 p38 MAPK의 억제제인 SB202190에 의해서 감소하였 다. 집먼지 진드기에 의해 활성화된 p38 MAPK은 protease-activated receptor (PAR2)의 억제제, rottlerin, SB202190에 의해 서 억제되었다. Serine protease 억제제인 aprotinin과 cysteine protease 억제제인 $\mathrm{E} 64$ 은 림프구의 사이토카인의 증가와 관련이 없었다. 또한 집먼지 진드기에 의해 증가된 사이토카인의 변화는 천식과 알레르기 비염 환자에서 차이가 없었다. 림프구에서 집먼지 진드기에 의해서 분비되는 분자들은 호중구의 유주운동을 억제시 켰다. 본 연구를 통하여 집먼지진드기에 의해 유발되는 알레르기 질환의 병인기전을 규명하는데 유용한 결과가 될 것이다.

Acknowledgements: This paper was supported by Eulji University in 2015. We thank normal volunteers and allergic patients to participate in this study.

Funding: None

Conflict of interest: None

\section{References}

1. Friedmann PS. The role of dust mite antigen sensitization and atopic dermatitis. Clin Exp Allergy. 1999;29:869-872.

2. Holgate ST. Pathogenesis of asthma. Clin Exp Allergy. 2008; 38(6):872-897.

3. Kang BK, Kim MA, Park SH, Lee EJ, Kim JS, Kim EJ, et al. The house dust mite allergen, Dermatophagoides pteronyssinus regulates the constitutive apoptosis and cytokine secretion of human eosinophils. Biomed Sci Lett. 2014;20:39-42.

4. Kim IS, Kim EH, Kim DH, Kim JS, Lee JS. Effect of house dust mite and CCL2 on S100A8 and S100A9 expression in human monocytes. Biomed Sci Lett. 2013;19:344-347.

5. Kim IS, Lee NR, Lee JS. Der p 1 inhibits spontaneous neutrophil apoptosis by cytokine secretion of normal and allergic lymphocytes. Korean J Clin Lab Sci. 2015,47(4):230-236.

6. Jacquet A. The role of innate immunity activation in house dust mite allergy. Trends Mol. 2011;17(10):604-611.

7. Tsai JJ, Liu SH, Yin SC, Yang CN, Hsu HS, Chen WB, et al. Mite allergen Der-p2 triggers human B lymphocyte activation and Toll-like receptor-4 induction. PLoS One. 2011;6(9):e23249.

8. Yang EJ, Choi E, Ko J, Kim DH, Lee JS. Differential effect of CCL2 on constitutive neutrophil apoptosis between normal and asthmatic subjects. J Cell Physiol. 2012; 227(6):2567-2577.

9. Kim DH, Choi E, Lee JS, Lee NR, Baek SY, Gu A, et al. House dust mite allergen regulates constitutive apoptosis of normal and asthmatic neutrophils via toll-like receptor 4. PLoS One. 2015;10:e0125983.

10. Kim EH, Lee JS, Lee NR, Baek SY, Kim EJ, Lee SJ, et al. Regulation of constitutive neutrophil apoptosis due to house dust mite allergen in normal and allergic rhinitis subjects. PLoS One. 2014;9:e105814.

11. Takizawa H. Bronchial epithelial cells in allergic reactions. Curr Drug Targets Inflamm Allergy. 2005;4(3):305-311.

12. Rossi D, Zlotnik A. The biology of chemokines and their receptors. Annu Rev Immunol. 2000;18:217-242.

13. Shakoory B, Fitzgerald SM, Lee SA, Chi DS, Krishnaswamy G. The role of human mast cell-derived cytokines in eosinophil biology. J Interferon Cytokine Res. 2004;24:271-281.

14. Lee NR, Baek SY, Gu A, Kim da H, Kim SY, Lee JS, et al. House dust mite allergen suppresses neutrophil apoptosis by cytokine release via PAR2 in normal and allergic lymphocytes. Immunol Res. 2016;64(1):123-132.

15. Lee SE, Jeong SK, Lee SH. Protease and protease-activated receptor-2 signaling in the pathogenesis of atopic dermatitis. Yonsei Med J. 2010;51(6):808-822.

16. Walker JK, DeFea KA. Role for $\beta$-arrestin in mediating paradoxical $\beta 2 A R$ and PAR2 signaling in asthma. Curr Opin Pharmacol. 2014;16:142-147.

17. Samokhin GP, Jirousek MR, Ways DK, Henriksen RA. Effects of protein kinase $\mathrm{C}$ inhibitors on thromboxane production by thrombin-stimulated platelets. Eur J Pharmacol. 1999;386(2-3): 297-303.

18. van der Merwe JQ, Moreau F, MacNaughton WK. Protease-activated receptor-2 stimulates intestinal epithelial chloride transport through activation of PLC and selective PKC isoforms. Am J Physiol Gastrointest Liver Physiol. 2009;296(6):G1258- 
1266.

19. Thomas WR, Hales BJ, Smith WA. House dust mite allergens in asthma and allergy. Trends Mol Med. 2010;16(7): 321-328.
20. Gregory LG, Lloyd CM. Orchestrating house dust mite-associated allergy in the lung. Trends Immunol. 2011;32(9):402411. 